\title{
胃内 $\mathrm{pH}$ モニタ用テレメータカプセル†
}

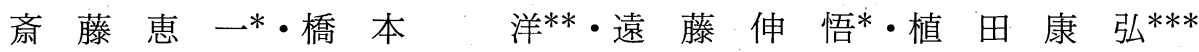 \\ 水野均***.工藤 正宏***.内 山明彦*
}

Telemetry Capsule for Gastric pH Monitoring

\author{
Keiichi Saito*, Hiroshi Hashimoto**, Shingo Endo*, Yasuhiro UedA***, \\ Hitoshi Mızuno***, Masahiro Kudo ${ }^{* * *}$ and Akihiko UChiYAmA*
}

This paper presents a telemetry capsule for measuring gastric $\mathrm{pH}$. The electrode of the new capsule is iridium oxide. Contrary to an antimony electrode, this iridium electrode does not possess toxicity and is more solid than a glass electrode. The electromotive force and the diameter of the iridium electrode is $57 \mathrm{mV} / \mathrm{pH}$ and $0.25 \mathrm{~mm}$. The process of modulation is PFM-FM, because the instability of the frequency of the FM circuit lacks reliability to $\mathrm{pH}$ monitoring using telemetry. The PFM circuit is a voltage controlled oscillator (VCO) circuit. The current consumption of VCO is $770 \mu \mathrm{A}$. The range of the frequency variation is less than $\pm 10 \mathrm{~Hz}$ when the center frequency of VCO is $6.54 \mathrm{kHz}$. The voltage of the power supply which is two $1.5 \mathrm{~V}$ silver oxide batteries is held in $2.5 \mathrm{~V}$ by two voltage regulators. The electronic circuits required for the capsule were customized into 2 hybrid ICs. The capsule diameter and length are $12 \mathrm{~mm}$ and $28.5 \mathrm{~mm}$. The total current consumption of the electronic circuit is $3.51 \mathrm{~mA}$. The measurable time is 2.5 hours and the error is $0.2 \mathrm{pH}$. In order to confirm the usableness of our capsule, the gastric $\mathrm{pH}$ of a fasted dog was monitored. 'After confirming that the capsule was in the stomach with an endoscope, ranitidine which is and inhibitor of acid secretion was injected to the dog's vein in order to measure $\mathrm{pH}$ alteration. After intravenous injection, $\mathrm{pH}$ value started to increase from $\mathrm{pH} 1.5$ to $\mathrm{pH} 4$ remarkably. Though the suction pump and the driver of the endoscope were working during this measurement, the demodulated wave form was not influenced by the electromagnetic noise of these devices. We conclude that our capsule is usable to measure gastric $\mathrm{pH}$. Further studies, however, are necessary for improvement of the miniaturization of capsule size for clinical application.

Key Words : biotelemetry, gastric $\mathrm{pH}$, capsule, iridium oxide electrode

\section{1.はじめに}

胃内 $\mathrm{pH}$ 計測は, 病態の解明や薬剤の効果判定に用い られている1),2).たとえば, 難治性潰瘍の入院患者に対し,

$\dagger 12$ th International Symposium on Biotelemetry で発 表 $(1992 \cdot 9)$

* 早稲田大学理工学部 東京都新宿区大久保 3-4-1

** 東京女子医大成人医学センター 東京都渋谷区渋谷 2-15-1

*** オリンパス光学工業(株) 八王子市石川町 2951

* School of Science and Engineering, Waseda University, Shinjuku-ku, Tokyo

** Tokyo Women's Medical College, Shibuya-ku, Tokyo

*** Olympus Optical CO., LTD., Hachiouji

(Received November 19, 1993)

(Revised October 3, 1994)
ガラス電極を経鼻的に胃内に挿入し，長時間の胃内 $\mathrm{pH}$ のモニタリングをして，抗潰瑒薬の効果判定をすること がある.しかし，患者の大半である外来患者に対し，こ の検査法を用いることは事実上難しい，そこで，外来で 簡単に，しかも患者に大きなストレスをかけずに，抗潰 隍薬の選択，投与量の決定，効果判定を行える方法が開 発されれば有用となる可能性がある。

本研究の目的は, 胃内 $\mathrm{pH}$ 計測の重要性 ${ }^{3)}$ と生体テレ メトリの有用性 ${ }^{4)}$ に着目し, 簡便で, 患者にストレスのか からない，胃内 $\mathrm{pH}$ 計測用のテレメータシステムを開発 することである ${ }^{5) 77 . ~}$

これまでに,テレメータカプセルによる胃内 $\mathrm{pH}$ 計測 の試みは多くなされてきだ) 100.従来のカプセルでは,セ ンサであるアンチモン電極の安全性やガラス電極の高内 部抵抗，小型化の難しさや堅牢性の問題などが指摘され 


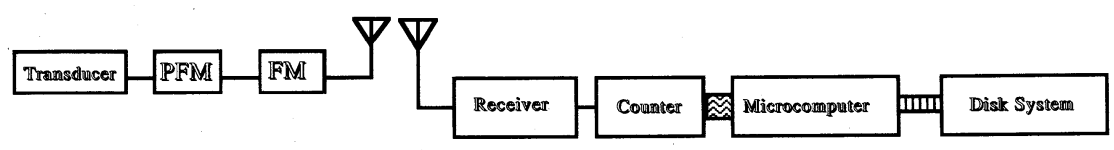

Fig. 1 Block diagram of capsule and monitoring system

てきた ${ }^{11}$.また, 従来は指摘されていなかったが, 変調回 路の周波数変動や電源電圧の変動からくる $\mathrm{pH}$ 情報の信 頼性の低下の問題もある.

これに対し本論文では，アンチモン電極より安全性に すぐれ，ガラス電極より小型化が容易で堅牢性のある酸 化イリジウム電極を用い, 二重変調方式とボルテージ・ レギュレータにより $\mathrm{pH}$ 情報の信頼性低下に対応したカ プセルを試作したので報告する.

\section{2. 胃内 $\mathrm{pH}$ 計測システム}

\section{1 送信用カプセル}

Fig. 1 に計測システムのブロック図を示す．胃酸の水 素イオン濃度の情報は, センサにより電圧に変換される。 この電圧をパルス周波数変調(以下 PFM と略す) 回路で パルス周波数に変換する。さらに，このパルスで搬送波 を周波数変調 (以下 FM と略す) し, 情報を体外に送信す る.

カプセルはセンサ部, 電子回路部(PFM-FM 回路) お3 よび電源部から構成される(Fig. 2).

（1） センサ部

$\mathrm{pH}$ 電極に酸化イリジウム電極を用いた ${ }^{12), 13)}$ ・イリジ ウムは白金族に属し最も不活発な金属である，その酸化 物も塩酸に溶けず，生体毒性に対する安全性はアンチモ ン電極よりはるかに優れている. $\mathrm{pH}$ 応答機構はアンチ モン電極と同じである．また，ガラス電極より小型化し やすく，機械的にも丈夫である.

参照電極は, 内部電極と接する溶液の污染を防ぐため, 2 槽構造にした。それぞれの槽には，塩化カリウム溶液 (3.3 M) が満たされている.特に第 1 槽の内部液は, ヒド ロキシセルロースでゲル化されている．内部電極は第 1 槽に固定されている．第 2 槽は第 1 槽の外側にあり，サ ンプルと接触するようになっている，それぞれの槽とサ ンプルは，アルミナ製多孔質セラッミクを通し液絡され ている。

今回使用した $\mathrm{pH}$ 電極と従来使用したガラス電極の基 礎特性を Table 1 に示す.また,この電極の $\mathrm{pH}$ 濃度対出 力電圧特性を Fig. 3 に示す.

(2) PFM-FM 回路

病院内テレメトリでは，各種検査機器からの電磁放射 ノイズを考慮する必要がある。そこで搬送波の変調はノ

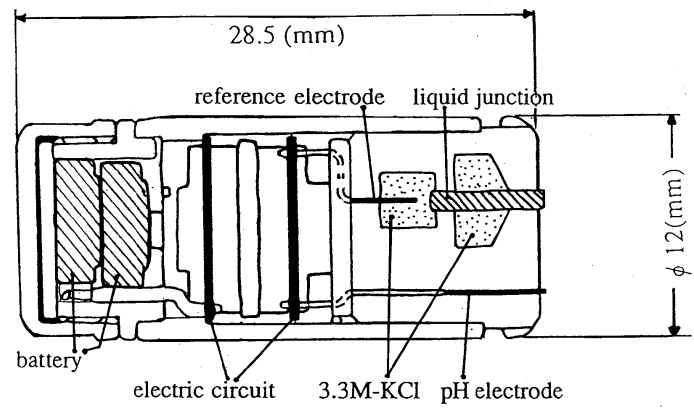

Fig. 2 Structure of the capsule

Table 1 Characteristics of $\mathrm{pH}$ electrodes

\begin{tabular}{c|c|c}
\hline \hline & Iridium oxide & Glass \\
\hline Electromotive force & $57 \mathrm{mV} / \mathrm{pH}$ & $55 \mathrm{mV} / \mathrm{pH}$ \\
Internal resistance & $2 \sim 3 \mathrm{k} \Omega$ & $1500 \mathrm{M} \Omega$ \\
Response time & $10 \mathrm{~s}$ & $60 \mathrm{~s}$ \\
Accuracy & $0.05 \mathrm{pH}$ & $0.03 \mathrm{pH}$ \\
Measuring range & $\mathrm{pH} 1 \sim \mathrm{pH} 14$ & $\mathrm{pH} 1 \sim \mathrm{pH} 14$ \\
Size & $\phi 0.25 \mathrm{~mm}$ & $\phi 1.6 \mathrm{~mm}$ \\
\hline
\end{tabular}

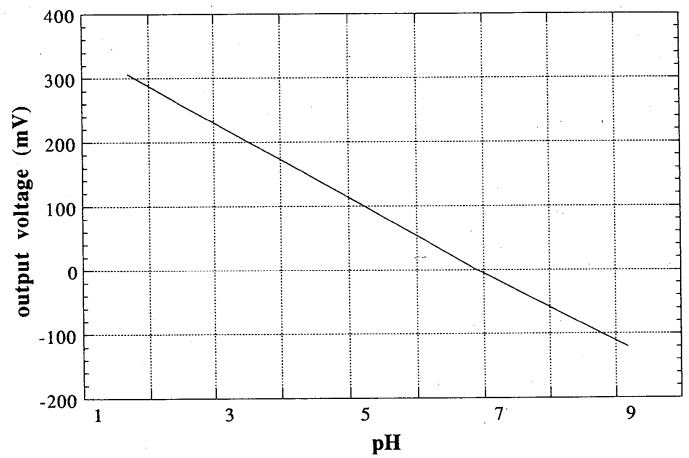

Fig. 3 Input/Output characteristics of $\mathrm{pH}$ sensor

イズに強い FM とした. カプセルをできる限り小型化 し，低消費電力で動作させるために，回路をできる限り 簡略化する必要がある。しかし，センサからの出力電圧 で FM 回路を直接変調した場合, $\mathrm{pH}$ 情報の信頼性が著 しく低下するが，従来の報告ではこの問題への対策は報 告されてこなかった。 そこで, 本カプセルでは, $\mathrm{pH}$ の情 報(電圧)をパルス周波数に変換しておき，このパルス周 


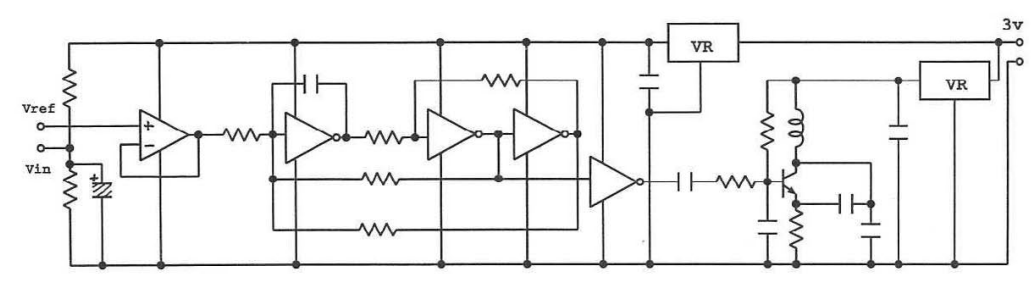

Fig. 4 Electronic Circuit of Capsule

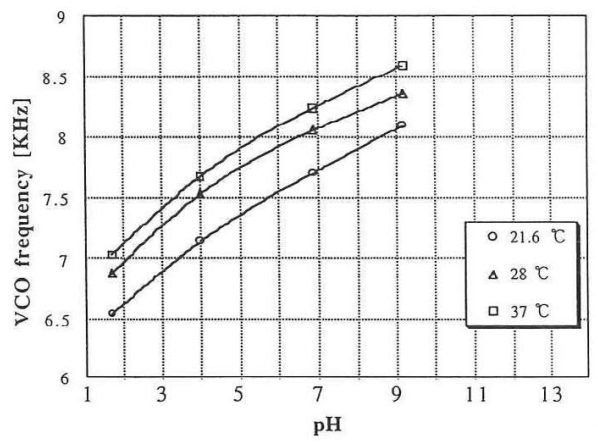

Fig. 5 Characteristics of $\mathrm{pH}-\mathrm{VCO}$ frequency

波数で周波数変調する二重変調方式をとりこの問題に対 応した. Fig. 4 に回路図を示す。

PFM 回路は, C-MOS インバータを用いた電圧一周波 数変換回路(以下 VCO と略す)である。駆動電圧は 2.5 $\mathrm{V}$, 動作時の消費電流は $770 \mu \mathrm{A}$ である。 $\mathrm{pH} 1.68$ 標準溶 液の 2.5 時間連続計測による変動幅は土0.039 pH で あった。

Fig. 5 に VCOの発振周波数と $\mathrm{pH}$ の関係を示す。セ ンサの入出力特性は直線的(Fig. 3)であるから，この非 直線性の原因はVCO の特性である。この特性は, 標準溶 液によるキャリブレーションを行えば, 計測上の問題は ない.

\section{(3) 電源部}

電源は酸化銀電池 $(26 \mathrm{mAh})$ で，これを 2 個直列に使 用した。電源電圧の変動は, VCO および FM 回路の周波 数の安定性に大きく影響し, データの信頼性低下や受信 状態の悪化につながるが, 従来報告されたカプセルでは, その検討はなされていなかった。そこで，今回試作した カプセルでは, チップ型ボルテージ・レギュレータを使 用し，駆動電圧 $(2.5 \mathrm{~V})$ の安定化をはかった。

(4) 外 観

Photo. 1 に試作したハイブリッド IC 基板, カプセル および電池を示す. IC 基板は 2 枚とも両面実装されてい る。消化液の侵食性を考慮し, カプセルの外装には高分 子材料のノリルを使用した。


Photo. 1 Telemetry Capsule, Batteries and Circuit assembly

\section{2 受信システム}

受信システムはFig. 1 に示した構成になっている. キャリブレーションは， pH 標準溶液 $(\mathrm{pH} 1.68 ， 4.01$, 6.86,9.18)による 4 点校正である.サンプリング間隔は, 必要に応じて変えることができる。

\section{3. カプセルの特性}

上述のシステムを用いて，試作したカプセルの動作確 認実験を行った。まず，再現性を確認するために，pH の 異なる標準溶液を繰り返し測定した.Fig. 6 に標準溶液 を順に取り替えたときの測定值の変化を示す。同一溶液 の計測誤差は $0.2 \mathrm{pH}$ 以内であった。

さらに経時安定性を確認するために，同一の標準溶液 を連続測定した。胃内 $\mathrm{pH}$ を考慮し, $\mathrm{pH} 1.68$ 標準溶液を 用いた. 150 分間の連続測定による $\mathrm{pH}$ の変動範囲は 0.2 以内であった(Fig. 7).

搬送波の周波数は約 $80 \mathrm{MHz}$, 消費電流は $3.51 \mathrm{~mA}$ (うち FM 回路が $86 \%$ ), 連続測定可能な時間は 2.5 時間 であった。

また, Fig. 3 に示したように，VCO の周波数は温度の 


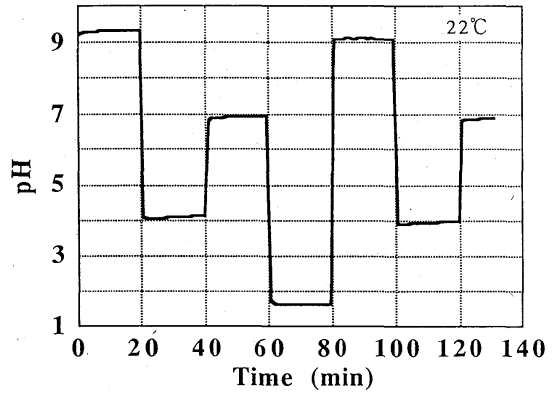

Fig. 6 Alteration of $\mathrm{pH}$ corresponding to four different buffer solutions



Fig. 7. Stability test of capsule

上昇とともに変化する. $\mathrm{pH} 1.68$ 標準溶液の $1^{\circ} \mathrm{C}$ 当たり の変化は約 $0.125 \mathrm{pH}$ であった. キャリブレーションに は生体内温度付近の標準溶液を使用する必要がある。力 プセルの温度依存性の原因は, センサの特性のほかに, 回路素子の特性が大きいと考えられる。したがって，大 きな温度変化がある場合，VCO のみならず FM 回路の 周波数も大きく変化するため, 温度変化を確認すること ができる．また，測定中は，飲食をしないことが好まし いが, 飲食に伴う温度の変化は一時的なもので, 計測上 は問題ないと考えられる。

\section{4. 動 物 実 験}

雑種成犬による実験で, 試作したカプセルによる胃内 $\mathrm{pH}$ 計測の可能性を検討した．生体内で発射された電波 は, 周囲の生体組織に吸収され, 体表面に至るまでに減 衰するそそのため生体内部から送信された電波を受信す る場合, 空中よりも受信状態が悪化する可能性がある.

そこで, 胃内の胃液 $\mathrm{pH}$ 計測と同時に, 計測中の復調波 形を観察した。まず計測直前に 4 点キャリブレーション を行った. 標準溶液の温度は大の体温を考慮して $38^{\circ} \mathrm{C} と$ した．カプセルが挿入途中で破壊されないように，前日 朝食以後禁食させた雑種成犬に，内視鏡を用いてカプセ

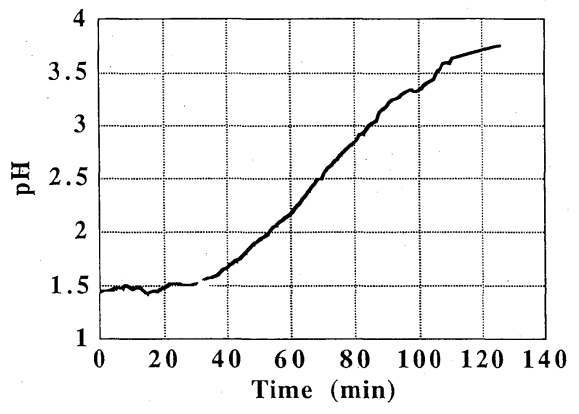

Fig. 8 Alteration of dog's gastric pH

ルを挿入した。カプセルが胃に到達したことを内視鏡で 確認したのち計測を開始した。受信デー夕処理システム の計測間隔は 1 分 1 回とし, 計測装置の液晶画面にその つどプロットした。

胃内 $\mathrm{pH}$ の経時変化を Fig. 8 に示す。計測開始時の $\mathrm{pH}$ は約 1.5 であった。これは, 空腹時としては妥当な值 と考えられる，再度カプセルが胃内にあることを内視鏡 で確認したのち, 胃内 $\mathrm{pH}$ の変化を確認するため, 計測開 始から約 30 分後に胃酸分泌阻害剂の塩酸ラニチジンを 通常の約 3 倍量筋注した。投与の 2 分後から $\mathrm{pH}$ が急激 に上昇し，胃内の無酸状態といわれる $\mathrm{pH} 4$ 亿近づく様 子が確認された。計測中に内視鏡駆動装置と吸引ポンプ を駆動させた場合でも，カウンタの值に不規則な乱れは 確認されなかった。

つぎに，市販の FM 受信機を犬の体表より徐々に離し てゆき，復調波形の変化を観察した。体表から約 $80 \mathrm{~cm}$ までは受信波形に乱れはなくカウンタの值も変化は見ら れず，安定した計測を行うことができた。実際の計測て は，受信機は身体に接触させることを前提としており， 送信用カプセルは胃内の $\mathrm{pH}$ 計測に十分な出力をもつこ とが確認された。

\section{5. おわりに}

胃内 $\mathrm{pH}$ 計測用のテレメータカプセルを試作しその特 性について述べた。さらに，雑種成犬を用いた実験によ り，胃内 $\mathrm{pH}$ を計測し得た。

胃内 $\mathrm{pH}$ 計測用テレメータカプセルは，簡便にかつ患 者にストレスを与えることなく, 抗潰場薬の効果判定, Zollinger-Ellison 症候群の病態判定 ${ }^{14)}$ への利用のほか に, 胃と十二指腸の $\mathrm{pH}$ の違いを利用して, 糖尿病患者に 多い胃内通過時間の増大を正確に計測することで，胃腸 機能調整剤の適用決定に用いることができると考えられ る ${ }^{15}$.さらに, 飲食による胃内の $\mathrm{pH}$ 変化を, 生理的かつ 連続的に計測することで，各飲食物の潰崵に対する影響 
を調べることも可能である16).

そのため, 今後実用化に向けさらにカプセルの小型化 をはかる。具体的には, センサ, 電子回路部の小型化と カプセル外壁の肉厚の検討を行う。さらに, 受信システ ムを携帯可能な大きさに小型, 軽量化する予定である.

本研究を進めるにあたりご協力頂いた日本光電工業

(株)の陳引氏，電極の開発にご協力頂いた東亜電波工業

(株)に感謝致します。

\section{参 考 文 献}

1）芦田，大柴：難治性潰瘍の今日的な考え方，治療，71-10, 119/124(1989)

2）渡辺：酸と潰瘍のかかわり, Modern Physician, 10-3, $267 / 270(1990)$

3）綿貫, 河合：今日の消化器病の診断と治療, 329/338, 医 学図書出版 (1972)

4) A. Uchiyama: Future Trend of Biotelemetry in Medicine, Proce. of the 11 th Int. Symposium on Biotelemetry, 17/19 (1990)

5) K. Saito, et al. : Radio Telemetry Capsule for Monitoring $\mathrm{pH}$ and Temperature in the Digestive Tract, Proce. of the 11 th Int. Symposium on Biotelemetry, 315/317 (1990)

6) K. Saito, et al.: Radio Telemetry Capsule for Monitoring $\mathrm{pH}$ and Temperature in Digestive Tract, Proc. of 1991 Japan Int. Electronic Manufacturing Technology Symposium, 168/170 (1991)

7）遠藤, 斎藤, ほか：消化管内 $\mathrm{pH}$ 計測用カプセルの開発, 第 32 回日本工ム・イー学会大会論文集，197 (1993)

8) 吉沢, ほか: アチドール・ペプシン顆粒のラジオカプセル 法による作用洔間の測定, 新薬と臨床, 17, 1705/ 1708(1968)

9）吉沢, ほか：胃疾患患者におけるマーロックスの使用経験 並びにラジオカプセルのテレメータリングによる胃液の pH 值の測定について，新薬と臨床，18，329/337(1969)

10）河井,ほか：胃粘膜保護作用を持つ消化性潰瘍剤の胃内制 酸持続効果に関する研究, 薬物療法, 10, 1193/1203(1977)

11）綿貫, ほか：生体テレメータ・電気刺激装置, $77 / 85$, コ ロナ社(1980)

12）加藤, ほか: 酸化イリジウム $\mathrm{pH}$ センサ, 日本分析化学会 第 39 回講演要旨集, 302(1990)

13) T. Katsube, et al: "METOX pH SENSOR" AS pH MEASURING ELECTRODE, International Congress on Analytical Science 1991, ABSTRACT, 439 (1991)

14）矢花，ほか：胃・十二指腸潰瘍，医学と薬学，22-6,1131/ 1439 (1989)

15) J.E. Berk et al: "Gastroenterology", 2, 1305/1327, W. B. SAUNDERS COMPANY (1985)

16) J. E. Berk et al : "Gastroenterology", 2, 1121/1123, W. B. SAUNDERS COMPANY (1985)

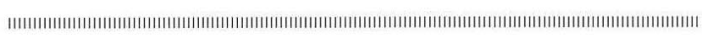
[著 者紹 介]



- (正会員)

1985 年, 早稲田大学理工学研究科修士課 程修了. 同年三共 (株) 入社. 86 年 87 年東 京大学医学部医用電子研究施設受託研究 員. 94 年より早稲田大学理工学総合研究セ ンター研究嘱託。医用電子工学の研究に従 事. 日本 $M E$ 学会の会員.

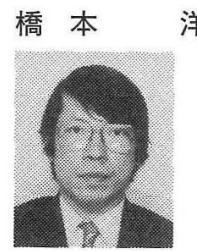

1982 年, 富山医科薬科大学医学部卒業. 同年東京女子医科大学消化器病センター内 科入局. 93 年より東京女子医科大学成人医 学セン夕一勤務。消化器内視鏡診断学, 超 音波内視鏡などの研究に従事(医学博士)。 日本消化器病学会認定医.

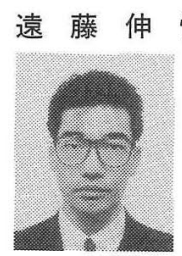

1993 年, 早稲田大学理工学部電子通信学 科卒業。現在司大学大学院修士課程在学中。 東京都老人総合研究所研究生.バイオテレ メトリ扔よび医用画像処理の研究に従事. 電子情報通信学会, 日本 ME 学会などの会 員.

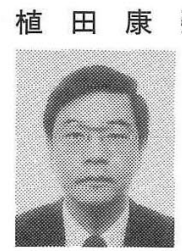

1980 年, 早稲田大学理工学部卒業。同年 オリンパス光学工業 (株) 入社. 内視鏡の開 発. マイクロマシン研究に従事. 現在第 3 開発部研究 1 グループリーダー。

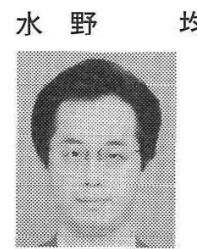

1983 年, 東京工業大学精密機械システム 修士課程を修了。ロボットメーカ勤務を経 て, 92 年オリンパス光学工業(株)に入社. 現在, マイクロマシン, ロボット工学の内 視鏡分野への応用研究・開発に従事。

\section{工藤 正 宏}

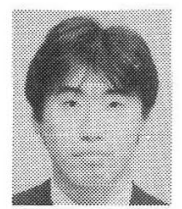

1989 年, 明治大学工学部電気工学科卒 業. 同年オリンパス光学工業 (株) 入社。内 視鏡の開発に従事. 
内山明彦

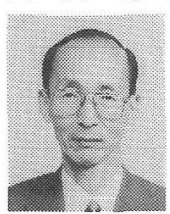

1958 年, 早稲田大学理工学部電気通信学 科卒業. 58 年 $~ 60$ 年東京大学工学部応用物 理学科助手. 60 年早稲田大学理工学部助 手. 73 年早稲田大学理工学部教授, 現在に 至る.医用電子計測の研究に従事. 日本 $\mathrm{ME}$ 学会, 電気学会などの会員 (工学博士). 